\title{
The door is open, but not everyone may enter: racial inequities in healthcare access across three Brazilian surveys
}

\author{
A porta está aberta, mas nem todos podem entrar: iniquidades \\ raciais no acesso à saúde em três inquéritos brasileiros
}

Helena Mendes Constante (https://orcid.org/0000-0001-9475-5786) ${ }^{1}$

Gerson Luiz Marinho (https://orcid.org/0000-0002-2430-3896) ${ }^{2}$

João Luiz Bastos (https://orcid.org/0000-0002-1816-0745) ${ }^{1}$

${ }^{1}$ Programa de PósGraduação em Saúde

Coletiva, Universidade Federal de Santa Catarina.

Campus Universitário Trindade. 88040-970

Florianópolis SC Brasil. lenaconstante@gmail.com

${ }^{2}$ Departamento de Enfermagem de Saúde Pública, Escola de Enfermagem Anna Nery, Universidade Federal do Rio de Janeiro. Rio de Janeiro RJ Brasil.

\begin{abstract}
Health policies in Brazil have sought to expand healthcare access and mitigate inequities, but recent revisions of their content have weakened the Brazilian Unified Health System. This study estimates three healthcare indicators across three national surveys conducted in 2008, 2013, and 2019 to assess the impact of changes to the National Primary Care Policy on racial inequities in healthcare. Considering the survey design and sampling weights, we estimated the prevalence of each outcome among both whites and Blacks for the whole country, and according to the Brazilian regions. We test the following hypotheses: compared to whites, Blacks showed higher frequency of coverage by the Family Health Strategy, lower frequency of health insurance coverage, and higher frequency of perceived difficulty accessing health services (H1); Racial inequities decreased in the ten-year period but remained constant between 2013-2019 (H2); Racial gaps have widened among regions with lower proportions of Blacks (H3). Our findings fully support $\mathrm{H} 1$, but not $\mathrm{H} 2$ and H3. Racial inequities either remained constant or decreased in the 2013-2019 period. By downplaying the importance of the universality and equity principles, the latest revision of the National Primary Care Policy has contributed to the persistence of racial inequities in healthcare.

Key words Race factors, Healthcare disparities, Brazil, Racism
\end{abstract}

Resumo As políticas de saúde no Brasil têm buscado expandir o acesso e mitigar as iniquidades, mas recentes revisões de seu conteúdo enfraqueceram o Sistema Único de Saúde. Este estudo estima três indicadores de saúde em três inquéritos nacionais, realizados em 2008, 2013 e 2019, para avaliar o impacto das mudanças na Política Nacional de Atenção Básica sobre as iniquidades raciais na saúde. Considerando o desenho da pesquisa e os pesos amostrais, estimou-se a prevalência de cada desfecho entre indivíduos brancos e negros para todo o país e segundo suas macrorregiões. Testamos as hipóteses: comparados aos brancos, negros apresentaram frequência maior de cobertura pela Estratégia Saúde da Família, menor de cobertura de plano de saúde e maior de dificuldade de acesso aos serviços (H1); as iniquidades raciais diminuíram no período de dez anos, mas estagnaram entre 2013-2019 (H2); as iniquidades raciais aumentaram entre as regiões com menores proporções de negros $(\mathrm{H} 3)$. Os resultados apoiam integralmente $\mathrm{H1}$, mas não $\mathrm{H} 2$ e H3. As iniquidades raciais permaneceram estáveis ou diminuíram entre 20132019. Ao contrapor os princípios de universalidade e equidade, a última revisão da Política Nacional de Atenção Básica contribuiu para a persistência das iniquidades raciais na saúde.

Palavras-chave Fatores raciais, Disparidades em assistência à saúde, Brasil, Racismo 


\section{Introduction}

Inequities in healthcare access represent a breach of human rights, which result from unfair and avoidable social processes ${ }^{1}$ that benefit some groups at the expense of others. In order to reduce healthcare inequities, not only should we target all dimensions of health services, but we must also promote public policies aimed at constructing fairer societies where the risk of becoming ill or dying prematurely is low for everyone $e^{2}$.

In a global monitoring report to track access to care, though, the World Health Organization highlighted that half of the world's population lacks access to quality health services ${ }^{3}$. This report showed that inequities in healthcare access are an issue for both central and periphery countries $^{4-6}$, but especially among those with no universal health systems ${ }^{7}$. In Brazil, universal healthcare is a constitutional right, since the promulgation of the 1988 Constitution, although it has been underappreciated in recent years, particularly under Michel Temer and Jair Bolsonaro's administrations ${ }^{8,9}$. Undeniably, the Unified Health System (Sistema Único de Saúde, hereafter abbreviated as SUS, according to its official name in Portuguese) is essential for promoting wellbeing, preventing and reducing the burden of adverse health outcomes among a population of around 210 million people, but especially among the neediest. Equitable care is thus particularly important for Black Brazilians and other socially marginalized groups (e.g., women, LGBTQ+ people, Indigenous populations etc.), who have historically shown the worst health conditions across the entire population.

Previous state-level efforts to address healthcare inequities have been fundamentally important to improve the health of all Brazilians ${ }^{10,11}$. Little has been done, however, to counteract racism in the domain of health services ${ }^{12}$. As racially minoritized individuals depend more heavily on the healthcare system, broader strategies aimed at reducing inequities, especially those exacerbated by racism, are needed. Such strategies should aim at redressing the historical oppression that places Black Brazilians at social-spatial locations characterized by varying degrees of marginalization $^{13-15}$. The comprehensive healthcare model currently in practice in Brazil - through the Family Health Strategy (FHS) - has been on the back burner of governmental priorities, though (see Giovanella, Franco ${ }^{16}$ ) for a discussion on the current situation faced by Brazilians to achieve the universal right to health). This model was prior- itized in the 2006 National Primary Care Policy (hereafter abbreviated as PNAB, according to its name in Portuguese), but such policy has been revised in 2011 and 2017. It is, therefore, essential to evaluate the impact of recent policy changes on racial inequities in healthcare.

Building on a recent publication ${ }^{17}$ that documented racial inequities in difficulty accessing health services in Brazil, the present study analyses racial inequities in healthcare over a period of ten years. The study aimed to estimate racial inequities in access to health services in three different policy scenarios. More specifically, access to health services was evaluated through (1) coverage by the FHS, (2) access to health insurance, and (3) perceived difficulty accessing health services, based on nationally-representative data available for 2008, 2013 and 2019. These years were under the influence of the first, second, and third versions of the PNAB - discussed at greater length below -, as each was approved by the Brazilian Ministry of Health in 2006, 2011, and 2017, respectively.

\section{Racial inequities in Brazil}

Black Brazilians are not only ill-represented in politics ${ }^{18}$ and privileged social positions ${ }^{19}$ (such as among medical ${ }^{20}$ and dental professionals ${ }^{21}$, but are also more likely to be poor $^{22}$ and live in impoverished regions of the country ${ }^{23}$, compared to their privileged white counterparts. Existing evidence also points to prevailing healthcare inequities. Black Brazilians are less likely to have visited the health services recently, have lower health insurance coverage, and are more likely to be mistreated by a health professional ${ }^{24-28}$. Moreover, Black Brazilians are largely concentrated in Northern and Northeastern regions of the country, which are notoriously known for their lower levels of healthcare availability ${ }^{29}$.

These inequities are not the result of chance, as they reflect a system of structuring opportunity and assigning value[,] based on the social interpretation of how one looks that unfairly disadvantages some individuals and communities, [while] unfairly advantages others ${ }^{30}$. In other words, these inequities are the result of racism in its multiple forms. It is racism, conceptualized as both a structuring component of contemporary societies and as personally-mediated mistreatment ${ }^{31}$, that operates to produce higher frequencies of negative health statuses among Black Brazilians ${ }^{32,33}$, who will then depend more heavily on healthcare ${ }^{34}$. 
The higher demand for care by the Black population is tangled with the equity principle of the SUS: the neediest should be prioritized. The current model of care has been active in the country since the 1988 Constitution, and it is responsible for regulating, supervising, controlling, and executing actions and services that promote health and prevent disease among the population. The proposition of universal and equitable healthcare is necessary, as these two specific issues (i.e., adequate provision of services and reduction of healthcare inequities) are generally seen as the change from a technical model - a model of care centered on medical doctors and hospital assistance - to a model of comprehensive care, the primary care model.

More broadly employed in the United States of America, the hospitalocentric model is focused on improving results at the individual patient level, as well as the use of costly technological resources. In contrast, the primary care model focuses on intersectoral actions and community participation to not only address the burden of diseases, but also promote health at the individual and population levels ${ }^{6,35} 36$. In 1995, the Family Health Program (later called Family Health Strategy - FHS) was implemented to reorient primary care in Brazil towards a more interdisciplinary and integral model of care, which would be closer to the primary care mode ${ }^{37}$. According to FHS, a basic health team is composed of a physician, a nurse, a nurse assistant, and four to six community health agents.

Throughout the past three decades, there was an expressive increase in the FHS coverage: the proportion of the population covered by health teams has grown from just over 4\% in 1998 to about $70 \%$ in 2017 . Of note, such an increase has been associated with a $45 \%$ decline in admissions to hospitals due to ambulatory care sensitive conditions $^{38}$. Related to the racial inequities in healthcare later assessed in this study, increasing coverage levels by the FHS has been associated with a reduction of $15 \%$ in the mortality gap between Blacks and whites ${ }^{39}$.

\section{National Primary Care Policy}

The regionalization of healthcare in Brazil has originally aimed to reduce financial barriers and inequities among the country's regions, as a means to achieve universal and equitable care. By implementing the Community Health Agents Program (Programa de Agentes Comunitários de Saude, in Portuguese), and then the FHS, the
Brazilian health system began to move from a technical model to a comprehensive one, based on the principles of the primary care model, ${ }^{40}$ in the early 1990s. This was possible by encouraging the decentralization of the system through the Basic Operational Standard (Norma Operacional Básica, in Portuguese) in 1996, and, later, the establishment of the PNAB, in 2006. In its first edition, the PNAB was considered to be groundbreaking. The policy guided the organization of the system, consolidating the composition of health teams by acknowledging community health agents as a professional category, and their fundamental importance in increasing healthcare access among peripheric communities, especially through monitoring of specific groups and public health issues.

In 2011 and 2017, the PNAB was revised, but within two very different political and economic scenarios (see the policy timeline by C Gomes ${ }^{41}$ ). In the first revision, the focus was on expanding the universality principle, while improving the quality of primary care. The Primary Care Baseline (Piso da Atenção Básica, in Portuguese), which allocated resources for the FHS based on the size of the population and the need to promote targeted policies, started to be based on social vulnerability indicators at the municipal level and the performance of health teams ${ }^{42}$. Meanwhile, the country went through a tremendous economic and political crisis, which resulted in a parliamentary coup in 2016. During this period, though concerns were raised by the time of its publication $^{43}$, a second revision of the PNAB was published with significant consequences for the health of the population. To summarize the consequences of the 2017 PNAB revision, EA Melo ${ }^{44}$ underline that the words "democratic" and "humanization" of care were removed from the policy text. The current PNAB changed the structure of FHS by reducing the number of community health agents per health team, constraining social policies, and expanding the participation of the private sector through low-budget health plans ${ }^{45}$.

Right after PNAB's first publication in 2006, the Brazilian Government launched a policy entitled "National Policy for the Integral Health of the Black Population" (Política Nacional de Saúde Integral da População Negra, in Portuguese) which, all limitations considered ${ }^{12}$, is still in force ${ }^{46}$. According to this policy, the actions and services aimed at the Black population should adhere to PNAB's core propositions. Because PNSIPN is a specific policy that not only recognizes the health needs of racially minoritized groups but 
also aims at promoting equity, PNAB's ensuing revisions may have had a substantial impact on racial inequities in healthcare. In particular, discontinuity and underfunding of services, as well as the lack of more decisive actions to eliminate inequities among marginalized groups all impede the SUS to truly reach its universality and equity principles ${ }^{40,47}$.

\section{Hypotheses}

We seek to evaluate health policies in Brazil, particularly their impacts on the achievement of two principles of the SUS: universality and equity. This study thus takes into consideration the most recent PNAB review to assess whether changes to its framing and content resulted in the worsening of racial healthcare inequities. Given that data are available for three specific years, it is possible to compare changes between each one of them, as well as analyze changes over a ten-year period. Of note, racism, a wide-ranging social process underlying racialized minorities' lower access to health services and lower quality of $\mathrm{care}^{48}$, is assessed here with its corresponding social marker: race ${ }^{49}$. Based on the above, we test three hypotheses: First, compared to whites, Blacks presented higher frequency of coverage by the FHS, lower frequency of health insurance coverage, and higher frequency of perceived difficulty accessing health services (H1); Second, racial inequities decreased over the ten-year period, but remained constant between 2013 and 2019 (H2); And, third, racial gaps have widened among regions with lower proportions of Blacks (H3).

\section{Method}

Data used in this study come from three household surveys whose interviews took place in 2008, 2013, and 2019. The first survey is the 2008 National Household Sample Survey (PNAD, according to its name in Portuguese), which comprised 271,677 respondents 18 years of age and over. The second and third surveys are part of the National Health Survey (2013 PNS and 2019 PNS), which included 145,580 and 207,845 respondents 18 years of age and over, respectively. In all surveys, sample selection was carried out in three stages using a cluster sampling procedure with probability proportional to size. The municipalities were chosen first, followed by the selection of census tracts, and households. Further details on each survey and their sampling structures can be found elsewhere ${ }^{50-52}$. The microdata is publicly available through the following website: https://www.ibge.gov.br/estatisticas/ downloads-estatisticas.html.

In order to assess racial inequities in healthcare, three self-reported outcomes were used: 1) Coverage by the FHS, measured through the question "Is your household registered in the family health unit?"; 2) Health insurance coverage was assessed by asking whether or not respondents had any private health insurance, medical or dental, from a private company or public body; and 3) Difficulty accessing health services, evaluated by combining answers to two questions (i) "The first time you sought health care in the past two weeks, did you get assistance?"; (ii) "Why have you not sought health care in the last two weeks?" Respondents who answered "No" to the first question and reported any reason other than "did not need (care)" for the second were classified as perceiving difficulty accessing healthcare.

Self-reported color/race (as it is officially named in Brazil, but here referred to as "race") was determined according to the categories adopted by the Brazilian Institute of Geography and Statistics: 1) white; 2) Black; 3) Yellow; 4) Brown; and 5) Indigenous. Since this study aims to examine inequities between whites and Blacks, with the latter including Blacks and Browns dure to their shared history of slavery, economic exploitation, social stigmatization and political marginalization in Brazil ${ }^{15}$, Yellows and Indigenous peoples were excluded from the analysis. Additionally, inequities were also explored according to geographical location divided into North, Northeast, Southeast, Centre-West, and South.

The relative frequencies of the race variable as well as each indicator of healthcare access were presented along with their 95\% confidence intervals (95\% CIs), based on data from each of the surveys mentioned. Racial inequities in healthcare access were then determined by estimating the prevalence of each outcome among both whites and Blacks for the country as a whole, as well as according to the five Brazilian regions described above. Data from the 2008 PNAD, the 2013 PNS and the 2019 PNS were also used in this case. All analyses took the complex survey design and the sampling weights into account, using Stata, v. 16.0. The do-file with the Stata commands used in this study is available at https://github.com/lenaconstante/2021-CSCpublication. The survey protocol of each survey was approved by the Brazilian National Committee on Ethics in Human Research, and, at the 
The distribution of the sample, according to race and healthcare access indicators, is presented in Table 1. There was an increasing proportion of Blacks throughout the years: from less than half of the sample in 2008 (49.6\%) to more than half in 2019 (56.0\%). Coverage by the FHS increased significantly from 2008 to 2019 , with less than half of the sample being covered in the first survey year $(48.9 \%)$ to more than two thirds in the last one $(68.8 \%)$ ). Around $30 \%$ of the sample had private health insurance in the three investigated surveys. Perceived difficulty accessing health services was fairly constant across the three study years: around $3 \%$ of the sample reported this outcome in 2008, 2013, and 2019.

Coverage by the FHS increased over the ten years of observation (Table 2) among both whites and Blacks, but the increase was higher in the first than in the second period analyzed. Blacks had higher levels of coverage by the FHS over the years: while $55.6 \%$ and $73.0 \%$ of Blacks were covered in 2009 and 2019, respectively, the corresponding figures for whites were $42.5 \%$ and $63.4 \%$. Blacks, on the other hand, were less likely to be covered by health insurance, when compared to whites. Health insurance coverage was overall the same across the surveys, being always higher among whites compared to Blacks. Difficulty accessing health services remained fairly constant over time for both racialized groups; Blacks showed, nevertheless, higher frequencies throughout the entire period.

Racial inequities in coverage by the FHS were constant for all geographic regions between 2008

and 2019 (Table 3). In every region, though, Blacks showed higher coverage by the FHS than whites. Racial inequities in health insurance coverage remained stable throughout the years among each region. Racial inequities in difficulty accessing health services remained the same over the entire period of observation across all geographic regions, with Blacks consistently facing higher difficulty accessing health services.

\section{Discussion}

Drawing from a larger body of research on health services assessment ${ }^{38,39,53}$, as well as the broader literature on racial inequities in health ${ }^{54,55}$, we tested three different hypotheses in this study: compared to whites, Blacks showed a higher frequency of coverage by the FHS, lower frequency of health insurance coverage, and higher frequency of perceived difficulty accessing health services (H1); Racial inequities decreased in the ten-year period, but remained constant between 2013 and 2019 (H2); And, racial gaps have widened among regions with lower proportions of Blacks (H3). Following the estimation of a number of healthcare access indicators among both Brazilian whites and Blacks, our findings provide strong support for $\mathrm{H} 1$, but not $\mathrm{H} 2$ and $\mathrm{H} 3$.

That Blacks are more likely to be covered by the FHS is an empirical confirmation that the equity principle has been, to some degree, followed in the daily struggles of the SUS construction, supporting our H1. Given the various forms of oppression to which Black Brazilians are systematically subjected in the country ${ }^{56}$, higher demand for care is to be expected among this population subgroup $^{32}$. And, to a large extent, our results indicate that Blacks' higher demand for care has been met with higher coverage by the FHS. To-

Table 1. Distribution of the sample according to race and indicators of healthcare access. National Household Sample Survey (2008 PNAD), and Brazilian National Health Survey (2013 and 2019 PNS).

\begin{tabular}{lrrrrrr}
\hline \multirow{2}{*}{ Race and indicators of healthcare access } & \multicolumn{2}{c}{$\mathbf{2 0 0 8}$ PNAD } & \multicolumn{2}{c}{ 2013 PNS } & \multicolumn{2}{c}{ 2019 PNS } \\
\cline { 2 - 7 } & $\mathbf{\%}$ & $\mathbf{9 5 \% C I}$ & \% & $\mathbf{9 5 \% C I}$ & \multicolumn{1}{c}{$\%$} & $\mathbf{9 5 \% C I}$ \\
\hline Race & & & & & & \\
$\quad$ Whites & 50.4 & $49.6 ; 51.2$ & 48.2 & $47.4 ; 49.0$ & 44.0 & $43.2 ; 44.6$ \\
$\quad$ Blacks & 49.6 & $48.8 ; 50.4$ & 51.8 & $51.0 ; 52.6$ & 56.0 & $55.3 ; 56.7$ \\
Coverage by the FHS & 48.9 & $47.7 ; 50.1$ & 60.8 & $59.5 ; 62.0$ & 68.8 & $67.7 ; 69.9$ \\
Coverage by health insurance & 28.1 & $27.5 ; 28.8$ & 30.2 & $29.3 ; 31.1$ & 29.6 & $28.8 ; 30.4$ \\
Difficulty accessing health services in the last two weeks & 3.1 & $2.9 ; 3.3$ & 2.9 & $2.7 ; 3.2$ & 3.2 & $3.0 ; 3.4$ \\
\hline
\end{tabular}

95\% CI - 95\% Confidence Interval; FHS - Family Health Strategy. 
Table 2. Estimates of healthcare access according to race. National Household Sample Survey (2008 PNAD), and Brazilian National Health Survey (2013 and 2019 PNS).

\begin{tabular}{|c|c|c|c|c|c|c|}
\hline \multirow{2}{*}{ Indicators of healthcare access according to race } & \multicolumn{2}{|c|}{2008 PNAD } & \multicolumn{2}{|c|}{2013 PNS } & \multicolumn{2}{|c|}{2019 PNS } \\
\hline & $\%$ & $95 \% \mathrm{CI}$ & $\%$ & $95 \% \mathrm{CI}$ & $\%$ & $95 \% \mathrm{CI}$ \\
\hline \multicolumn{7}{|l|}{ Coverage by the FHS } \\
\hline Whites & 42.5 & $41.1 ; 43.9$ & 54.7 & $52.9 ; 56.5$ & 63.4 & $61.6 ; 65.1$ \\
\hline Blacks & 55.6 & $54.3 ; 56.9$ & 66.4 & $65.1 ; 67.7$ & 73.0 & $71.9 ; 74.1$ \\
\hline \multicolumn{7}{|l|}{ Coverage by health insurance } \\
\hline Whites & 36.9 & $36.2 ; 37.7$ & 39.8 & $38.4 ; 41.2$ & 39.9 & $38.7 ; 41.1$ \\
\hline Blacks & 18.9 & $18.3 ; 19.5$ & 21.1 & $20.2 ; 21.9$ & 21.6 & $20.9 ; 22.3$ \\
\hline \multicolumn{7}{|l|}{ Difficulty accessing health services in the last two weeks } \\
\hline Whites & 2.2 & $2.0 ; 2.3$ & 2.1 & $1.8 ; 2.4$ & 2.5 & $2.2 ; 2.8$ \\
\hline Blacks & 4.0 & $3.8 ; 4.3$ & 3.7 & $3.4 ; 4.1$ & 3.8 & $3.5 ; 4.1$ \\
\hline
\end{tabular}

95\% CI - 95\% Confidence Interval; FHS - Family Health Strategy.

Source: Estimates calculated by the authors based on the survey data analysed.

gether with the finding that Blacks have lower levels of health insurance coverage (supporting our $\mathrm{H1}$ ), this finding also reveals that racialized minorities rely more heavily on the SUS to address their healthcare needs. The SUS should be thus prepared to counterbalance the wider social injustices that underlie Black Brazilians' patterns of health, disease, and wellbeing across the country by way of providing services that are compatible with the demand for care ${ }^{46}$.

The higher coverage by the FHS among Blacks has not been followed by lower perceived difficulty accessing health services, though, which also confirms our H1. Mirroring previous research findings [HM Constante and JL Bastos ${ }^{17}$, who further adjusted the analysis for a range of covariates, such as level of education and gender], our results consistently show that perceived difficulty accessing health services was higher among Blacks than whites across the entire period of observation and in all Brazilian geographic regions. This subjective indicator of healthcare access may not be grounded on lived experiences within the health system, but can certainly affect healthcare seeking behaviors and the overall satisfaction with care, which will then influence future experiences with service provision. More importantly, racial inequities in perceived difficulty accessing health services cannot be explained by factors other than social processes that unfairly distribute resources, expectations, and experiences across racially dominant and minoritized groups in Brazil. As such, perceived difficulty accessing health services should also be targeted by broader health policies and healthcare systems. In fact, this needs to be viewed not as an indica- tor of structure or process, but a useful indicator of outcome in health services research, more broadly ${ }^{57}$.

Our $\mathrm{H} 2$ was premised on the idea the latest revisions to the PNAB $^{41-44,58}$ would decrease the pace of reduction in healthcare inequities over time. Our findings, however, indicate that this was not the case, even after PNAB's revision in 2017. It is very likely, though, that the effects of the latest PNAB revision will take longer to manifest, as they are part of an unprecedented political and economic crisis that took place in Brazil in 2016. One of the most concerning consequences of this crisis was the impoverishment of the Brazilian population, and disinvestment in a range of public policies, including the FHS and the conditional cash transfer program named Bolsa Família ${ }^{59}$.

The inverse equity hypothesis ${ }^{60}$ was the conceptual base for our H3. Following the notion that health-promoting interventions are adopted by more powerful regions and population groups first, we expected that Blacks living in Southern and Southeastern Brazil - characterized by higher proportions of whites - would be promptly affected by the PNAB's revisions. Such a chain of events would then contribute to increasing racial gaps in healthcare access within the wealthiest regions of the country. The results at which we arrived did not indicate that this has been the case, however, with racial inequities either remaining constant or decreasing in the 2013-2019 period, regardless of the proportion of Blacks observed in each Brazilian region. Again, the few time points that were available to analyze time trends in racial inequities in healthcare access limit our 


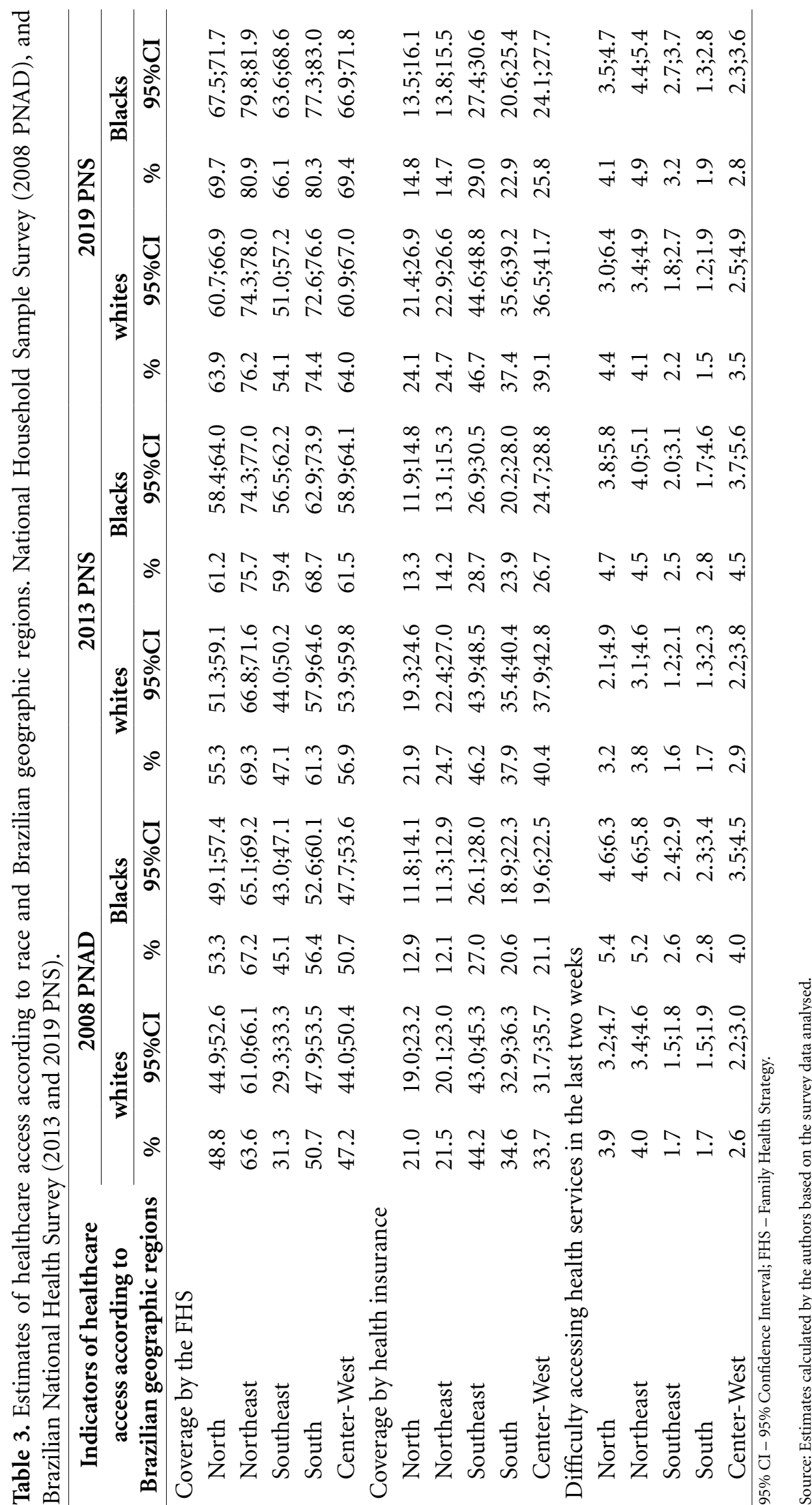


ability to determine whether PNAB's revisions will eventually worsen unfair patterns of access to health services. This issue should be continuously monitored, though, if the universality and equity principles are to be effectively achieved within the context of the SUS.

One major limitation of our study refers to the need to analyze public policy effects using multivariate models, as has previously been done in the wider medical literature ${ }^{59,61}$. This would allow us to consider the effects of other important social processes underlying patterns of racial inequities in healthcare access, and more precisely estimate the impacts of the PNAB's revisions on population health. The lack of observable effects (through lack of support for both $\mathrm{H} 2$ and H3), however, suggests that negative results do not stem from the need to use more sophisticated analytical techniques. Rather, our findings suggest that policy impacts may have longer induction and latency periods, which would justify continuous monitoring of the indicators outlined above. Above all, our study suggests that racial inequities in healthcare access will persist if public policies downplay the importance of the universality and equity principles - such is the case of perceived difficulty accessing health services. We know that the SUS's doors are wide open; healthier public policies are needed, though, so that everyone may enter when demand for care is an issue.

\section{Collaborations}

HM Constante contributed to the study conception and planning, performed the analyses, and was responsible for drafting the first version of this article, including revising its final version. GL Marinho participated in the study conception and planning, data interpretation, writing-up of elements of the article, and critically revising its final version. JL Bastos contributed to the study conception, planning, and design, reviewing the analyses and data interpretation, and writing the final version of the discussion, including revising the final version of this article.

\section{Acknowledgments}

Support to write this article was given to Dr Helena Mendes Constante by the Conselho Nacional de Desenvolvimento Científico e Tecnológico National (CNPq) [Council for Scientific and Technological Development] through a Postdoctoral Fellowship. Dr João Luiz Bastos was partially supported by the Brazilian National Research Council. 


\section{References}

1. Whitehead M. The concepts and principles of equity and health. Int J Health Serv 1992; 22(3):429-445.

2. Travassos C, Martins M. A review of concepts in health services access and utilization. Cad Saude Publica 2004; 20(Supl. 2):S190-198.

3. World Health Organization (WHO). Tracking universal health coverage: 2017 global monitoring report. World Health Organization and International Bank for Reconstruction and Development / The World Bank; 2017.

4. Long Q, Xu L, Bekedam H, Tang S. Changes in health expenditures in China in 2000s: has the health system reform improved affordability. Int $J$ Equity Health 2013; 12:40.

5. Dickman SL, Himmelstein DU, Woolhandler S. Inequality and the health-care system in the USA. Lancet 2017; 389(10077):1431-1441.

6. Giovanella L, Mendoza-Ruiz A, Pilar ACA, Rosa MCD, Martins GB, Santos IS, Silva DB, Vieira JML, Castro VCG, Silva POD, Machado CV. Universal health system and universal health coverage: assumptions and strategies. Cien Saude Colet 2018; 23(6):1763-1776.

7. Goddard M, Smith P. Equity of access to health care services: theory and evidence from the UK. Soc Sci Med 2001; 53(9):1149-1162.

8. Morosini M, Fonseca AF, Baptista TWF. Previne Brasil, the Agency for the Development of Primary Healthcare, and the Services Portfolio: radicalization of privatization policy in basic healthcare? Cad Saude Publica 2020; 36(9):e00040220.

9. Castro MC, Massuda A, Almeida G, Menezes-Filho NA, Andrade MV, Souza Noronha KVM, Rocha R, Macinko J, Hone T, Tasca R, Giovanella L, Malik AM, Werneck H, Fachini LA, Atun R. Brazil's unified health system: the first 30 years and prospects for the future. Lancet 2019; 394(10195):345-356.

10. Brasil. Ministério da Saúde (MS). Política Nacional de Saúde Integral da População Negra: uma política para o SUS. Brasília: MS; 2013.36 p.

11. Brasil. Ministério da Saúde (MS). HumanizaSUS: Política Nacional de Humanização: documento base para gestores e trabalhadores do SUS. In: Secretaria Executiva. Núcleo Técnico da Política Nacional de Humanização. Brasília: MS; 2004.

12. Batista LE, Barros S. Confronting racism in health services. Cad Saude Publica 2017; 33(Supl. 1):e00090516.

13. hiavegatto Filho AD, Beltran-Sanchez H, Kawachi I. Racial disparities in life expectancy in Brazil: challenges from a multiracial society. Am J Public Health 2014; 104(11):2156-2162.

14. Chor D. Health inequalities in Brazil: race matters. Cad Saude Publica 2013; 29(7):1272-1275.

15. Lopes F. [Beyond the numbers barrier: racial inequalities and health]. Cad Saude Publica 2005; 21(5):15951601.

16. Giovanella L, Franco CM, Almeida PF. National Primary Health Care Policy: where are we headed to? Cien Saude Colet 2020; 25(4):1475-1482.

17. Constante HM, Bastos JL. Mapping the margins in health services research: How does race intersect with gender, and socioeconomic status to shape difficulty accessing healthcare among unequal Brazilian States? Int J Health Serv 2021; 51(2):155-166.
18. Campos LA, Machado M. Raça e eleições no Brasil Porto Alegre: ZOUK; 2020. 168 p.

19. Salardi P. The Evolution of Gender and Racial Occupational Segregation Across Formal and Non-Formal Labor Markets in Brazil, 1987 to 2006. Rev Income Wealth 2016; 62(S1):S68-S89.

20. Scheffer M, Cassenote A, Guilloux AGA, Biancarelli A, Miotto BA, Mainardi GM. Demografia Médica no Brasil 2018. São Paulo: FMUSP, CFM, Cremesp; 2018. $286 \mathrm{p}$.

21. Morita M, Haddad AE, Araújo ME. Perfil atual e tendências do cirurgião-dentista brasileiro. Maringá: Dental Press International; 2010.

22. Pinheiro L, Fontoura NO, Querino AC, Bonetti A, Rosa W. Retrato das desigualdades de gênero e raça. Brasilia: IPEA; 2008. [acessado 2020 Nov 30]. Disponível em: http://goo.gl/qZarif.

23. Reichenheim ME, Souza ER, Moraes CL, Mello Jorge $\mathrm{MH}$, Silva CM, Souza Minayo MC. Violence and injuries in Brazil: the effect, progress made, and challenges ahead. Lancet 2011; 377(9781):1962-1975.

24. Souza EH, Oliveira PA, Paegle AC, Goes PS. [Race and the use of dental health services by the elderly]. Cien Saude Colet 2012;17(8):2063-2070.

25. Boccolini CS, Boccolini PM, Damacena GN, Ferreira AP, Szwarcwald CL. Factors associated with perceived discrimination in health services of Brazil: Results of the Brazilian National Health Survey, 2013. Cien Saude Colet 2016;21(2):371-378.

26. Boccolini CS, Souza Junior PR. Inequities in Healthcare utilization: results of the Brazilian National Health Survey, 2013. Int J Equity Health 2016;15(1):150.

27. Junior O, Menegazzo GR, Fagundes MLB, Sousa JL, Torres L, Giordani J. Perceived discrimination in health services and preventive dental attendance in Brazilian adults. Community Dent Oral Epidemiol 2020; 48(6):533-539.

28. Malta DC, Stopa SR, Pereira CA, Szwarcwald CL, Oliveira M, Reis AC. Private Health Care Coverage in the Brazilian population, according to the $2013 \mathrm{Bra}-$ zilian National Health Survey. Cien Saude Colet 2017; 22(1):179-190.

29. Stopa SR, Malta DC, Monteiro CN, Szwarcwald CL, Goldbaum M, Cesar CLG. Use of and access to health services in Brazil, 2013 National Health Survey. Rev Saude Publica 2017; 51(Supl. 1):3s.

30. Jones CP. Toward the science and practice of anti-racism: launching a national campaign against racism. Ethn Dis 2018; 28(Supl. 1):231-234.

31. Bailey SR. Legacies of Race: Identities, Attitudes, and Politics in Brazil: Stanford University Press; 2009.306 p.

32. Chor D, Lima CR. Epidemiologic aspects of racial inequalities in health in Brazil. Cad Saude Publica 2005; 21(5):1586-1594.

33. Oliveira RG, Cunha APD, Gadelha A, Carpio CG, Oliveira RB, Correa RM. Racial inequalities and death on the horizon: COVID-19 and structural racism. Cad Saude Publica 2020; 36(9):e00150120.

34. Silva ZP, Ribeiro MCSA, Barata RB, Almeida MF. Socio-demographic profile and utilization patterns of the public healthcare system (SUS), 2003-2008. Cien Saude Colet 2011; 16:3807-3816. 
35. Giovanella L, Almeida PF. [Comprehensive primary care and segmented health systems in South America]. Cad Saude Publica 2017; 33(Supl. 2):e00118816.

36. Nedel FB, Facchini LA, Martín M, Navarro A. Características da atenção básica associadas ao risco de internar por condições sensíveis à atenção primária: revisão sistemática da literatura. Epidemiol Serv Saude 2010; 19:61-75.

37. Macinko J, Harris MJ. Brazil's family health strategy-delivering community-based primary care in a universal health system. $N$ Engl J Med 2015; 372(23):2177-2181.

38. Pinto LF, Giovanella L. The Family Health Strategy: expanding access and reducing hospitalizations due to ambulatory care sensitive conditions (ACSC). Cien Saude Colet 2018; 23(6):1903-1914.

39. Hone T, Rasella D, Barreto ML, Majeed A, Millett C. Association between expansion of primary healthcare and racial inequalities in mortality amenable to primary care in Brazil: A national longitudinal analysis. PLoS Med 2017;14(5):e1002306.

40. Machado CV, Lima LD, Baptista TWF. Health policies in Brazil in times of contradiction: paths and pitfalls in the construction of a universal system. Cad Saude Publica 2017; 33(Supl. 2):e00129616.

41. Gomes C, Gutierrez AC, Soranz D. National Primary Care Policy 2017: analysis of teams composition and national coverage of Family Health. Cien Saude Colet $2020 ; 25(4): 1327-1338$.

42. Massuda A. Primary health care financing changes in the Brazilian Health System: advance ou setback? Cien Saude Colet 2020; 25(4):1181-1188.

43. Morosini MV, Fonseca AF. Reviewing the Brazilian National Primary Healthcare Policy at such a time? Cad Saude Publica 2017; 33(1):e00206316.

44. Melo EA, Mendonça MHM, Oliveira JR, Andrade GCL. [Changes in the National Policy of Primary Health Care: between setbacks and challenges]. Saude Debate 2018; 42:38-51.

45. Morosini MVGC, Fonseca AF, Lima LD. [National Policy of Primary Healthcare 2017: setbacks and risks to the Unified Health System]. Saude Debate 2018; 42:11-24.

46. Brasil. Ministério da Saúde (MS) Política Nacional de Saúde Integral da População Negra : uma política para o SUS. $3^{\text {a }}$ ed. Brasília: Ministério da Saúde. Secretaria de Gestão Estratégica e Participativa. Departamento de Apoio à Gestão Participativa e ao Controle Social; 2017. p. 44.

47. Souza L, Paim JS, Teixeira CF, Bahia L, Guimaraes R, Almeida-Filho N, Machado CV, Campos GW, Azevedo ESG. The current challenges of the fight for a universal right to health in Brazil. Cien Saude Colet 2019; 24(8):2783-2792.

48. Jones C. Confronting institutionalized racism. Phylon 2002 50:7-22.

49. Phelan JC, Link BG. Is Racism a Fundamental Cause of Inequalities in Health? Annu Rev Sociol 2015; 41(1):311-330.

50. Souza-Júnior PRB, Freitas MPS, Antonaci GA, Szwarcwald CL. Sampling Design for the National Health Survey, Brazil 2013. Epidemiol Serv Saude 2015; 24:207-216.
51. Szwarcwald CL, Malta DC, Pereira CA, Vieira ML, Conde WL, Souza Junior PR, Damacena GN, Azevedo LO, Azevedo ESG, Theme Filha MM, Lopes CS, Romero DE, Almeida WS, Monteiro CA. [National Health Survey in Brazil: design and methodology of application]. Cien Saude Colet 2014;19(2):333-342.

52. Travassos C, Viacava F, Laguardia J. Os Suplementos Saúde na Pesquisa Nacional por Amostra de Domicílios (PNAD) no Brasil. Rev Bras Epidemiol 2008; 11:98-112.

53. Hone T, Saraceni V, Medina Coeli C, Trajman A, Rasella D, Millett C, Durovni G. Primary healthcare expansion and mortality in Brazil's urban poor: A cohort analysis of 1.2 million adults. PLoS Med 2020; 17(10):e1003357.

54. Bailey ZD, Krieger N, Agenor M, Graves J, Linos N, Bassett MT. Structural racism and health inequities in the USA: evidence and interventions. Lancet 2017; 389(10077):1453-1463.

55. Bailey ZD, Feldman JM, Bassett MT. How Structural Racism Works - Racist Policies as a Root Cause of U.S. Racial Health Inequities. N Engl J Med 2020; 384:768773.

56. Muniz JO, Bastos JL. Classificatory volatility and (in) consistency of racial inequality. Cad Saude Publica 2017; 33(Supl. 1):e00082816.

57. Donabedian A. The role of outcomes in quality assessment and assurance. QRB Qual Rev Bull 1992; 18(11):356-360.

58. Almeida ER, Sousa ANA, Brandao CC, Carvalho FFB, Tavares G, Silva KC. National primary health care policy in Brazil: an analysis of the review process (20152017). Politica Nacional de Atencion Basica en Brasil: un analisis del proceso de revision (2015-2017). Rev Panam Salud Publica 2018; 42:e180.

59. Rasella D, Basu S, Hone T, Paes-Sousa R, Ocke-Reis CO, Millett C. Child morbidity and mortality associated with alternative policy responses to the economic crisis in Brazil: a nationwide microsimulation study. PLoS Med 2018; 15(5):e1002570.

60. Victora CG, Vaughan JP, Barros FC, Silva AC, Tomasi E. Explaining trends in inequities: evidence from Brazilian child health studies. Lancet 2000; 356(9235):1093-1098.

61. Rasella D, Hone T, de Souza LE, Tasca R, Basu S, Millett C. Mortality associated with alternative primary healthcare policies: a nationwide microsimulation modelling study in Brazil. BMC Med 2019; 17(1):82.

Article submitted 29/12/2020

Approved 18/02/2021

Final version submitted 20/02/2021

Chief editors: Maria Cecília de Souza Minayo, Romeu Gomes, Antônio Augusto Moura da Silva 